\title{
Soil physicochemical and ethnobiological studies on the peat swamp forests of Southern Papua, Indonesia
}

\author{
AKHMAD KADIR ${ }^{1,2}$, ROSYE H.R. TANJUNG ${ }^{2,3}$, SUHARNO ${ }^{2,3, \boldsymbol{v}}$, BASA T. RUMAHORBO ${ }^{2}$, \\ MUHAMMAD A. REZA \\ ${ }^{1}$ Department of Anthropology, Faculty of Social and Political Sciences, Universitas Cenderawasih. Jl. Kamp Wolker, Waena, Jayapura 99351, Papua, \\ Indonesia \\ ${ }^{2}$ Center of Environmental Studies, Universitas Cenderawasih. Jl. Kamp Wolker, Waena, Jayapura 99351, Papua, Indonesia \\ ${ }^{3}$ Program of Biology, Faculty of Mathematics and Natural Sciences, Universitas Cenderawasih. Jl. Kamp Wolker, Waena, Jayapura 99351, Papua, \\ Indonesia. Tel./fax. +62-967-572115. `email: harn774@yahoo.com. \\ ${ }^{4}$ Faculty of Engineering, Universitas Cenderawasih. Jl. Kamp Wolker, Waena, Jayapura 99351, Papua, Indonesia
}

Manuscript received: 14 January 2020. Revision accepted: 29 March 2020.

\begin{abstract}
Kadir A, Tanjung RHR, Suharno, Rumahorbo BT, Reza MA. 2020. Soil physicochemical and ethnobiological studies on the peat swamp forests of Southern Papua, Indonesia. Biodiversitas 21: 1714-1722. Peatlands play an important role in human life, particularly its direct impact for the locals. People in peatlands depend on the availability of natural resources, including in Papua. The purpose of this research was to determine the important role of peatland areas in the lives of locals in southern Papua. The survey was conducted using the purposive sampling method. Peat soil samples were analyzed at the Balai Penelitian dan Teknologi Pertanian (Agricultural Research and Technology Center) (BPTP) Yogyakarta. The results showed that peatlands in the southern part of Papua, specifically Mappi District, belong to the fibric peats category. Soil analysis results showed that the average pH is 4.04 (acidic), organic $\mathrm{C}$ is $16.39 \%$ (high), total $\mathrm{N}$ is $1.12 \%$ (very high), and $\mathrm{C} / \mathrm{N}$ ratio is 14.69 (moderate). In general, the local's knowledge about peat swamp is still low (26.98\%), most of them $(73.02 \%)$ do not know the existence of peat swamp forest. So far, people only know the forest as swamp forest. The locals still depend on forest areas to fulfill their daily needs, therefore peat areas land-use must be followed by wise management so that they can be made sustainable.
\end{abstract}

Keywords: The locals, peatland, Mappi, Southern Papua

\section{INTRODUCTION}

Peatland is an area that is naturally inundated frequently and in the form of swamp sand, therefore, it is often referred to as peat swamps. Peat swamp is one of the natural resources, has hydrological and environmental functions that are important for the life and survival of humans and other living things (Hansen et al. 2009; Posa et al. 2011). Thus the land-use of peatland resources must be done wisely through careful planning, proper management, and the application of appropriate technology. All of these interests relate to the quality and sustainability of nature (Wahyunto et al. 2006; Posa et al. 2011).

Based on several studies, the area of peatlands in Indonesia is estimated to be in the range of 13.5-26.5 million ha. According to Driessen (1978), the area of peatlands in Indonesia is 17 million hectares, around 9.7 million hectares spread in Sumatra, Kalimantan having 6.3 million hectares, and in Papua about 100,000 hectares. Meanwhile, according to Wibowo and Suyatno (1998) and Wahyunto et al. (2006), peat swamp is mostly found in four large islands, namely Sumatra (35\%), Kalimantan (32\%), Sulawesi (3\%) and Papua (30\%). Wahyunto et al. (2006) estimated that $30 \%$ of the peatland area in Papua reaches 5.1 million hectares.

Peat swampland has a type of swamp forest that is a specific and fragile ecosystem (Adi et al. 2004;
Chokkalingam et al. 2005; Barchia 2017). Peat ecosystem degradation is caused by several factors, including land-use changes, deforestation, illegal logging, forest fires, and others (Chokkalingam et al. 2005). For this reason, peatland management needs to be done wisely and carefully. If the management system is not carried out properly, the forest ecosystem will not be sustainable (Silvius and Suryadiputra 2005; Ratmini 2012). The types of vegetation that grow in peat swamp areas are very specific and have high economic value from both timber and non-timber forest products (Posa et al. 2011; Lubis 2013).

Peatlands serves to maintain and regulate the ongoing processes of ecosystem, by being water reservoirs (Hergoualch et al. 2018), sources of biodiversity (Page et al. 1999; Posa et al. 2011), carbon deposits (Rudiyanto et al. 2015; Barchia 2017), and others. The point is that peat forest areas are a natural source to meet people's welfare needs. Most of the southern region of Papua is a swampy lowland area, including the peat swamps. According to Hergoualch et al. (2018), people depend on their lives in the forest as a source of income and livelihood.

Managing peatland areas requires the involvement of various parties. The party directly involved is the community around the area. Therefore, the locals must understand the existence of peat forest areas, their functions and how to manage them based on local wisdom, 
along with the role of the government. The purpose of this research was to determine the existence and the land-use of peatlands by the locals in southern Papua.

\section{MATERIALS AND METHODS}

\section{Research area}

This research was conducted in 6 sub-districts, namely: Bamgi, Yakowi, Edera, Minyamur, Haju and Venaha of Mappi District, in the southern region of Papua Province, Indonesia (Figure 1). These sub-districts are swampland region and are expected as peatland. Observation and exploration of the peatlands were carried out in 10 villages of these six sub-districts (List of villages available in table 2).

\section{Peatland survey soil characteristics}

The peatland survey was carried out by visual observations and laboratory analysis of the samples. Soil sampling was done with the help of a drill tool. Soil samples were analyzed at the Balai Penelitian dan Teknologi Pertanian (Agricultural Research and Technology Center) (BPTP) Yogyakarta Testing Laboratory. The soil analysis involves soil $\mathrm{pH}, \mathrm{C}$ organic level, total $\mathrm{N}, \mathrm{C} / \mathrm{N}$ ratio, availability of $\mathrm{P}$, and other important elements such as $\mathrm{K}, \mathrm{Ca}, \mathrm{Na}, \mathrm{Mg}$, and soil texture. Peat characteristics were ascertained based on the results of laboratory analysis. The flora and fauna were identified based on the literature, in the form of a plant or animal identification book (Womersley 1995; Beehler et al. 2001; Ohee 2017).

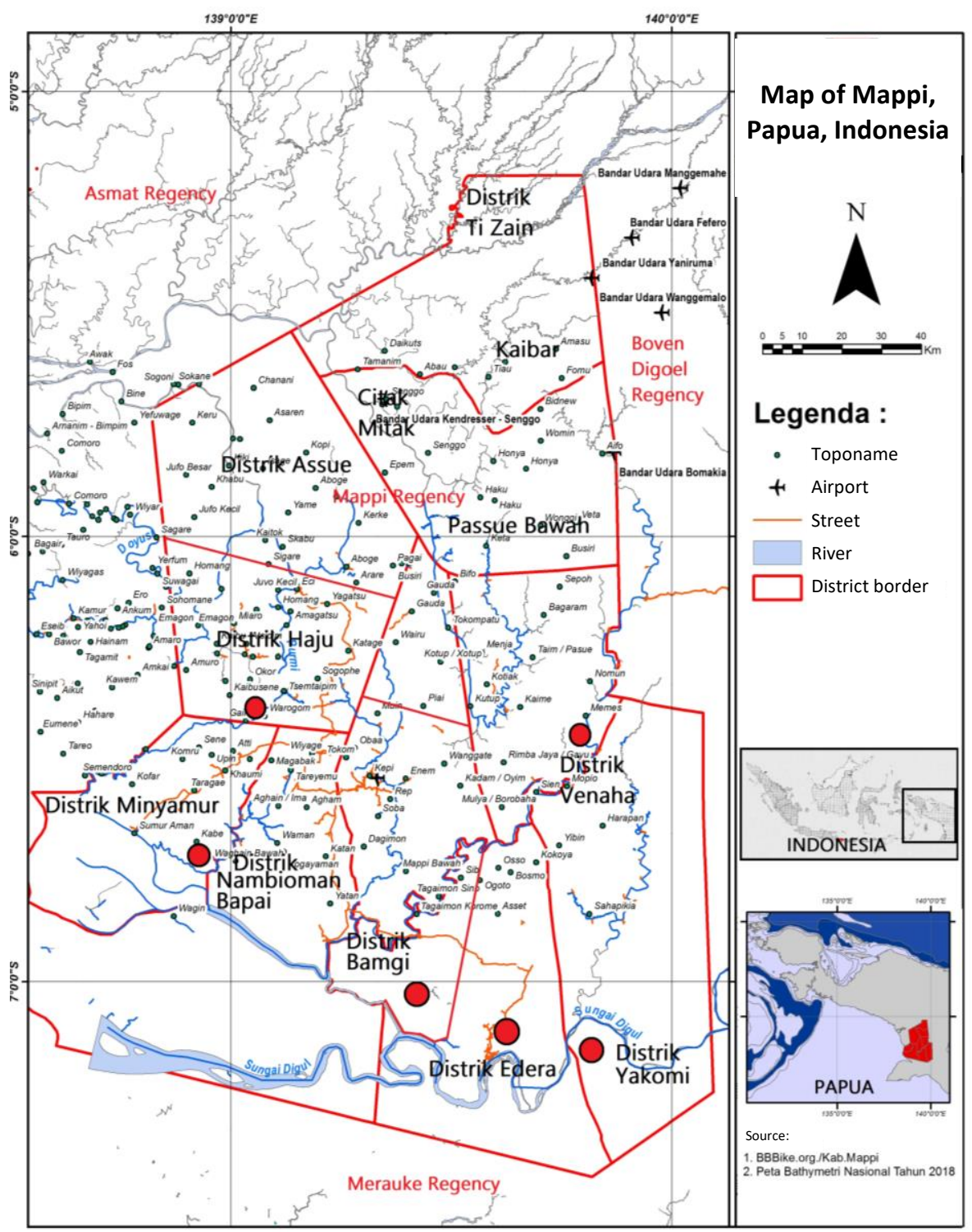

Figure 1. Peatland sampling location in Mappi, Papua, Indonesia 


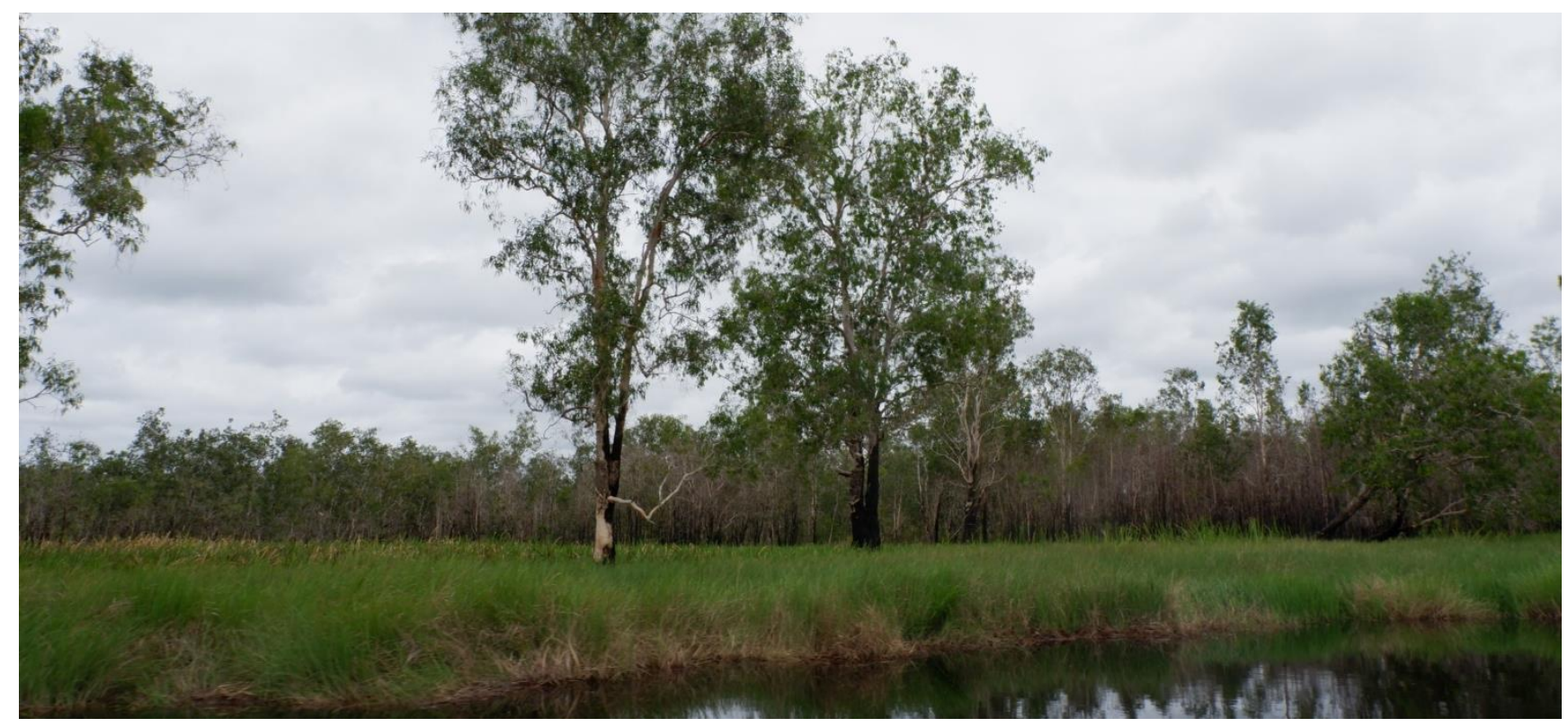

Figure 2. One of the peatland areas in Mappi District, Papua, Indonesia

\section{Peatland knowledge and land-use survey}

Information about the local understanding and land-use of peat swamp forest areas was conducted through interviews with selected sample of local residents in the vicinity of the peatland area. This important information is to overlook how far the locals understand and concern about the existence of peatland. The total number of respondents interviewed was 185 , consisting of key informants, traditional elders, and other members of the local communities.

Based on the socio-cultural aspects of the Mappi indigenous people, the area of coverage is known as the 'Wilayah Kebudayaan Mappi' (Mappi Cultural Territory). This region extends from the border of Merauke District (Digoel River and Muara Digoel area) to parts of the border areas of Asmat District (Asmat River), Boven Digoel, and Merauke. The Auyu Tribe or Auyu people live between the Digoel rivers, area of Merauke and Mappi District, Papua Province. Therefore, samples and interviews were conducted in Mappi District. This area is full of forests and swamps, and is dominated by grasslands (Melalatoa 1995).

\section{RESULTS AND DISCUSSION}

\section{Characteristics of peatlands}

The survey showed that peatlands are found in Mappi District (Wetland International Indonesia Programme 2006; Figure 2). Physically, the presence of peat is indicated by the dark brown color of river water. Many tributaries empty into the Digoel River, which is the largest river in the Region. In other parts of the swamp area, stagnant water is dark brown to blackish brown. In some soil sampling locations, drilling was carried out at a depth of $80 \mathrm{~cm}$, while in other parts it reached $300 \mathrm{~cm}$. The level of peat thickness is estimated to range between $10-60 \mathrm{~cm}$. The results of soil analysis showed that the acidity $\left(\mathrm{pH}: \mathrm{H}_{2} \mathrm{O}\right)$ ranges from 3.89 to 4.19 , with an average of 4.08 which is classified as acidic.

Organic C content was between $15.27 \%-17.54 \%$, with an average of $16.39 \%$ which is in the category of high. The total $\mathrm{N}$ content ranges from $1.09-1.14 \%$ with an average of $1.12 \%$ in the category of very high. The $\mathrm{C} / \mathrm{N}$ ratio was between 13.39-15.66, with an average of 14.69 (moderate) (Table 1). According to Barchia (2017), most peat soils have a $\mathrm{pH}<4.0$, high organic $\mathrm{C}$ content and $\mathrm{C} / \mathrm{N}$ ratio. Peat in Central Kalimantan has a pH ranging from 3.25 to 3.60 and organic $\mathrm{C}$ content ranging from $51.00 \%$ to $58.00 \%$. But, in Mappi it was only around $16.39 \%$ which is much lower. The $\mathrm{C} / \mathrm{N}$ ratio was also far lower than observed in Kalimantan which reached 31-49. According to Sorensen (1993), Warren et al. (2017), and Winarso (2005), the high content of $\mathrm{C}$ is related to the value of carbon stocks in the area. High carbon content in peatlands is one source of carbon stock in the environment.

The available $\mathrm{P}$ content ranges from $8-10 \mathrm{ppm}$, with an average of $9.0 \mathrm{ppm}$ (very low). Meanwhile, the $\mathrm{K}$ content is around $0.40 \mathrm{cmol} . \mathrm{kg}-1$ (very high), Ca $0.47 \mathrm{cmol.kg}-1$ (low), and $\mathrm{Mg} 0.78 \mathrm{cmol.kg}-1$ (very high). The value of cation exchange capacity (CEC) of land was between 22.86-34.93 cmol.kg-1 with an average of 28.78 (moderate-high), with a saturation level of bases (BS) of around $7.77 \%$. All these results of soil analysis indicate that peat soil in the study area has a texture from clay loam to sandy-silt loam. Judging from these characteristics, peat soils in this area belong to the category of fibric peat (Barchia 2017). 
Table 1. Characteristics of peat soils in study locations of Mappi District, Papua, Indonesia

\begin{tabular}{|c|c|c|c|c|c|}
\hline \multirow{2}{*}{\multicolumn{2}{|c|}{ Physicochemical characteristics of peat soils }} & \multicolumn{3}{|c|}{ Location of sampling } & \multirow[t]{2}{*}{ Avg } \\
\hline & & \multirow{2}{*}{$\begin{array}{lr} & \text { Yel_B } \\
4.17 & \end{array}$} & \multirow{2}{*}{$\begin{array}{l}\text { Kab_M } \\
3.89\end{array}$} & Kon_B & \\
\hline $\mathrm{pH}(\mathrm{H} 2 \mathrm{O})$ & & & & 4.19 & 4.08 \\
\hline $\mathrm{pH}(\mathrm{KCl})$ & & 3.65 & 3.36 & 3.65 & 3.55 \\
\hline Organic C & $(\%)$ & 16.37 & 17.54 & 15.27 & 16.39 \\
\hline $\mathrm{N}$ total & $(\%)$ & 1.09 & 1.12 & 1.14 & 1.12 \\
\hline C/N Ratio & & 15.01 & 15.66 & 13.39 & 14.69 \\
\hline $\mathrm{P}$ available & $(\mathrm{ppm})$ & 10.00 & 9.00 & 8.00 & 9.00 \\
\hline K-dd & (cmol.kg-1) & 0.44 & 0.40 & 0.36 & 0.40 \\
\hline Ca-dd & (cmol.kg-1) & 0.76 & 0.51 & 0.13 & 0.47 \\
\hline $\mathrm{Na}-\mathrm{dd}$ & (cmol.kg-1) & 0.31 & 0.29 & 0.25 & 0.28 \\
\hline Mg-dd & (cmol.kg-1) & 1.09 & 0.98 & 0.27 & 0.78 \\
\hline CEC & (cmol.kg-1) & 22.86 & 28.54 & 34.93 & 28.78 \\
\hline Base saturation & $(\%)$ & 11.29 & 9.15 & 2.87 & 7.77 \\
\hline \multicolumn{6}{|l|}{ Al-HddKCl 1N: } \\
\hline Al-dd & (me.100g-1) & 2.20 & 2.21 & 2.48 & 2.30 \\
\hline $\mathrm{H}-\mathrm{dd}$ & (me.100g-1) & 6.33 & 5.93 & 5.90 & 6.05 \\
\hline \multicolumn{6}{|l|}{ Soil texture } \\
\hline Sand & $(\%)$ & 27.67 & 20.00 & 3.00 & 16.89 \\
\hline Silt & $(\%)$ & 44.33 & 55.32 & 63.00 & 41.44 \\
\hline Clay & $(\%)$ & 28.00 & 24.68 & 34.00 & 28.89 \\
\hline
\end{tabular}

Notes: Yel_B: Yeloba village (Bamgi Sub-district), Kab_M: Kabe Village (Minyamur Sub-district), Kon_B: Konebi village (Bamgi Subdistrict).

Table 2. Results of survey of the locals understanding on the existence of peat swamp forests in southern Papua, Mappi District, Papua, Indonesia

\begin{tabular}{|c|c|c|c|c|c|c|}
\hline \multirow[b]{2}{*}{ Sub-district } & \multirow[b]{2}{*}{ Village } & \multirow[b]{2}{*}{$\begin{array}{l}\text { No. of respondents } \\
\text { (n) }\end{array}$} & \multicolumn{4}{|c|}{ Local's knowledge } \\
\hline & & & $\begin{array}{c}\text { Peatland } \\
\text { Forests }\end{array}$ & $\%$ & Peat Swamps & $\%$ \\
\hline \multirow[t]{3}{*}{ Bamgi } & Yeloba & 20 & 20 & 100 & 7 & 35.0 \\
\hline & Konebi & 20 & 20 & 100 & 4 & 20.0 \\
\hline & Sibi & 25 & 23 & 92.0 & 6 & 24.0 \\
\hline Yakowi & Benggo & 15 & 14 & 93.3 & 3 & 20.0 \\
\hline \multirow[t]{2}{*}{ Edera } & Kogoya Satu & 20 & 20 & 100 & 5 & 25.0 \\
\hline & Puiya & 20 & 19 & 95.0 & 4 & 20.0 \\
\hline Minyamur & Kabe & 15 & 15 & 100 & 5 & 33.3 \\
\hline \multirow[t]{2}{*}{ Haju } & Abeska & 15 & 15 & 100 & 2 & 13.3 \\
\hline & Haju & 15 & 13 & 86.7 & 2 & 13.3 \\
\hline Venaha & Memes & 20 & 20 & 100 & 4 & 20.0 \\
\hline Rerata & & 185 & & 96.7 & & 26.9 \\
\hline
\end{tabular}

Note: $\mathrm{n}=185$ respondents

\section{Locals understanding of peat swamps}

Locals awareness of the existence of peat swamps is still low at only $26.98 \%$ (Table 2) and the remaining $73.02 \%$ are not aware of the existence of peat swamps. Even those who are aware have learned about peat swamp forest only about 2 years ago, because there has been a study and socialization of the peat forest area by the Badan Restorasi Gambut (Peat Restoration Agency) (BRG). The locals know it better as swamp forest, and only a few know of peat. The low level of understanding of the community must be improved by further socialization of all components of the community in Mappi District by Papua Province BRG. Previously, only some communities were involved in the socialization of peat swamp forests. This condition can be used as capital to carry out ongoing socialization in southern Papua.

The level of local's understanding of peat swamp forest areas is very important (Posa et al. 2011; Lubis 2013), because they relate to the use of biodiversity in the area (Silvius and Suryadiputra 2005; Posa et al. 2011). Local's understanding will also support better management and system planning (Ratmini 2012; Yule 2010). There must be a comprehensive management system between various parties, the community, government, and nongovernmental organizations. Papua has a community that has more than 250 tribes, the management must involve all these communities, especially the locals living around peatlands. 


\section{Local culture of hunting and gathering}

The Auyu tribe in Mappi District, in the southern part of Papua Province, is one of the large tribes in Mappi District who still maintain the heritage of their ancestors (Amias 2013). The Auyu ethnic group uses its own language, the Auyu language with a total of around 18,000 speakers. Included in this language group are Oser, Jenimu, Pisa, Wefu, and Iwkero languages. The Auyu are neighbors to the Asmat in the north, the Citak in the east, and the Yaqai in the south. In the past, the Auyu were known to wander, but after being embraced by the propagators of Catholicism, their habits changed and they live in settlements permanently (Melalatoa 1995).

The socio-cultural structure of the community which is in such a wide area range includes 12 indigenous tribes with a variety of languages and traditional customs characteristics, consisting of 4 (four) major tribes, namely: Auyu, Yaghai, Wiyaghar, and Kuruway Citak tribes (Koroway), and 8 (eight) minor tribes, namely: the KimaGhima tribe, the Asmat tribe, the Uyaghar tribe, the Sawi tribe, the Tamario tribe, the Atokhoim tribe, the Yelmek tribe, the Mitak tribe, and the Bismam tribe (Basman). Most of these tribes still have the pattern of life and sociocultural structure of the 'peramu' (gatherer).

The villages in Mappi District are almost partly located on the riverbanks. The wide and long river becomes the economic pulse, because it can connect one village to another. Indigenous communities in this area are building settlements along the riverbanks (Figure 3 ). This position is very strategic because it can be sailed by small and large ships which sometimes escape state supervision.

Communities living in this ecological zone defend their lives by gardening, fishing and tapping sago. The livelihood is a combination developed by Papuans living in coastal ecological zones, river mouths such as the Auyu tribe in Mappi District. Natural resource management is not over-exploited. Even though they use very simple tools, they can fulfill their daily needs. They are included in small-scale societies by relying on livelihoods on natural resources. Adaptation to the ecological environment is related to livelihoods, technological systems, and also influences other cultural aspects such as social organizations and ideological systems or belief systems.

The area occupied by the Auyu people is an area which until today has never dealt with matters relating to politics and security. This area includes the Peace Zone in the Papua region, especially South Papua. Until now, they are still very dependent on nature. Hunting in the forest with bow and arrows, sago tapping, drinking forest water directly, and also fishing from the river traditionally (fishing or closing the river with forest leaves during high tide and when the water recedes, they collect fish in the mud). They do not know the usage of nets, potas, fish stuns, fish bombs, or similar devices.

\section{Customary organizational structure and control of forest areas}

Auyu people recognize the clan system called kerel. The existence of the clan was guarded and defended by men. A clan can be defended through marriage or war. Through marriage, the clan can be extended, while with war the clan is defended from its extinction or not enslavement by other clans or ethnic groups. That is why their culture knows the game bukhose khave, a game that is usually played by boys. The name of the game can literally be translated as "galangal game", in which the instrument is made from the galangal (Alpinia galanga) trunk collected from the forest by spiking it on the other side. In this game the children identify themselves as war clansmen called poghoi, like poghoi in the days of their ancestors who made heroic events in the history of their groups or clans. They want the same as the head of the war generation of his ancestors who are considered very knights.

Both in the customary structure and in the governance structure, the chosen figures are key figures who can solve the problems internally and externally in the Auyu community. The expectations and trust of the Auyu people towards them are very high, so that they become very important figures and actors in resolving the community's social community in the village. According to Amias (2013), the Auyu tribe recognizes 3 charismatic figure models that influence leadership. First, Basing Maiyo (Orang Besar; Big Man). The Big Man is in the physical sense (a healthy body, rich in wealth because he is diligent in working in the garden and raising pigs, has his own big house, etc.). But, also in the sense of having a soul/mentality that likes to help people who are struggling, their home is open to all people and peaceful. This type of person is a person who is very worthy to be a leader. Second, Basing Maiyo Kao/Vreyo (Bukan Orang Besar; Not a Big Man). Someone is called Basing Maiyo $\mathrm{Kao} /$ Vreyo if he has a behavior that is contrary to Basing Maiyo (Orang Besar; Big Man) earlier. This type of person cannot be a leader. Third, Oviyo (Most People/Commoner). People belonging to Oviyo are those who do not have Basing Maiyo and Basing Maiyo Kao/Vreyo behavior. They have a flat and ordinary life. This type is likely to become a leader if he develops himself into Basing Maiyo (Big Person). It appears from these three types of human persons that the Auyu tribe has an open leadership model, that anyone can be a leader, provided he meets the criteria of Basing Maiyo (Big Man).

Land is an important component of population and customary defense. Land is considered as a defense tool, so people generally do not easily sell land. The point is that the tribes and their descendants will survive, because in the inherited land they can grow and develop. Besides the rules of customs and culture must also be developed, the younger generation must know the customs, culture and language. Auyu's customary land is located in the southern part of Papua and is spread over and controls the Mappi and Boven Digoel Districts as the owner of customary forests. In the possession of customary land rights, the Auyu people know them based on the clan inherited from patrilineal lineage boys. Customary land ownership is based on clans with clear boundaries between them. Customary land does not belong to sub-ethnic or ethnic groups but is entirely within the clan and the boundaries of customary territories per clan are marked in nature. The boundary uses signs that can be in the form of rocks, trees, rivers, banks, tillers, swamps and sago groves. 
Based on socio-cultural aspects, customary land is a former site of footprints or adventures in meeting the needs of the foraging landscape of the previous generation. Life moved in the period before settling into a village also influenced the determination of customary rights. Based on the expansion of meeting economic needs, then the boundaries of customary rights are then endless. Therefore, customary land rights are closely related to natural resources, and management of natural resources, so that land is interpreted as a "mother" who births life to next generations.

It is almost certain that the outermost border of the claimed customary land is not framed. However, leading local communities to claim that there is no land in Papua without its owner. All land has its owner and its ownership is communal, that is the common property which must be cultivated together by clans. The land that was originally no man's land changed into the concept of customary land rights belonging to a clan or clan formed on a totem. The myth of totem is defended because they direct them towards a collective life. These customary rights border become biased when neighboring villagers claim the same thing and refer to their ancestral stories told from one generation to the next, because the determination of customary land rights limits is in individual memory. Customary land has become something imaginable, even among those who have never seen firsthand the borders of their customary land.

\section{The use-value of peat areas for the locals}

The locals are highly dependent on the peat forest environment. The results of this study showed that the majority of the community used the forest as part of meeting their daily clothing, shelter, and food needs (Table $3)$. The pattern of land-use is based on the level of community needs. Most people forage forest products just to fulfill their daily needs. Consumption of local natural resources, such as gambir (Endiandra fulva), gaharu (agarwood, Aquilaria sp), arowana fish (Scleropage jardinii), Cenderawasih birds (Paradisaea spp.), pigs (Sus scrofa), deer (Cervus timorensis), and several other flora and fauna, is largely based on market demand through middlemen (collectors).

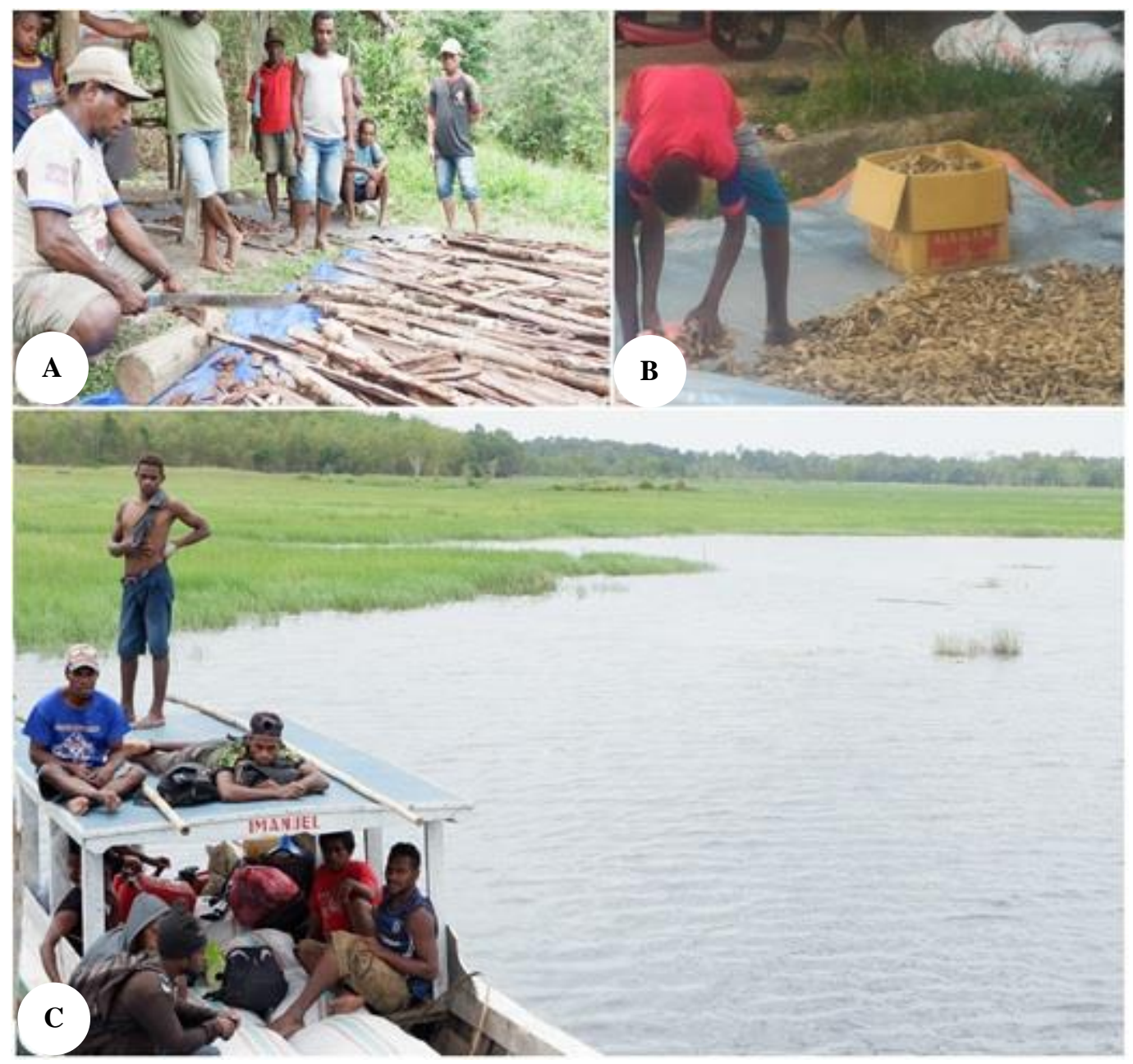

Figure 3. Use of some natural resources by the community in Mappi, Papua, Indonesia. A. The community processes gambier wood (Endiandra fulva), B. Agarwood (Aquilaria sp.), and C. Buyers/collectors transporting produces outside the region 
Table 3. Species of flora and fauna used by locals in the Peat Swamp Forest Area, Mappi, Papua, Indonesia

\begin{tabular}{|c|c|c|c|}
\hline $\begin{array}{l}\text { Groupflora } \\
\text { and fauna }\end{array}$ & $\begin{array}{c}\text { Indonesian and English } \\
\text { names }\end{array}$ & $\begin{array}{c}\text { Scientific name } \\
\text { (family) }\end{array}$ & $\begin{array}{l}\text { Importance } \\
\text { (product) }\end{array}$ \\
\hline \multirow[t]{7}{*}{ Plants } & Kakao/ Cacao & Theobroma cacao L. (Malvaceae) & Cacao seeds \\
\hline & Karet/ Rubber & Hevea brasiliensis (Willd.) Muell.-Arg. (Euphorbiaceae) & latex \\
\hline & Gaharu & Aquilaria sp. (Themeleaceae) & gaharu \\
\hline & Sagu/ Sago & Metroxylon sagu Rottb. (Palmae) & $\begin{array}{l}\text { sago starch, bark for walls, } \\
\text { leaves for roofs }\end{array}$ \\
\hline & Bus & Melaleuca Leucadendron (L.) L. (Myrtaceae) & Cajuput oil \\
\hline & Gambir & Endiandra fulva Teschn. (Lauraceae) & Gambir Barks \\
\hline & Masohi & Cryptocarya amassoy (Oken) Kosterm. (Lauraceae) & Essential Oil \\
\hline \multirow[t]{6}{*}{ Fishes } & Gabus Toraja/ Fish cork & Channa striata (Bloch, 1973). (Channidae) & Meat \\
\hline & Kakap Putih/White snapper & Lates calcarifer (Bloch, 1790). (Latidae). & Meat, Floaties \\
\hline & Ikan Sembilan/Eeltail catfish & Plotosus tanius (Hamilton, 1822). (Plotosidae). & Meat, Floaties \\
\hline & Kalosi/Arwana & Scleropages jardinii (Saville-Kent 1892). (Osteoglossidae) & Pets \\
\hline & Mujahir/ tilapia fish & Oreochromis mossambica (Peters, 1852) (Cichlidae) & Meat \\
\hline & Nila/ parrotfish & Oreochromis niloticus (Linnaeus, 1758). (Cichlidae). & Meat \\
\hline \multirow[t]{6}{*}{ Birds } & Cenderawasih & Paradisaea spp. (Parasidaidae) & accessories, custom rituals \\
\hline & Cenderawasih & Cicinnurus spp. (Alcedinidae) & accessories, custom rituals \\
\hline & Kasuari & Casuarius spp. (Casuariidae) & Meat \\
\hline & Mambruk & Goura spp. (Columbidae) & Meat \\
\hline & Maleo & Talegalla jobiensis(Megapodiidae) & Egg, meat \\
\hline & Kakatua/ Cockatoo & Probosciger sp. (Cacatuidae) & Pets \\
\hline \multirow[t]{2}{*}{ Others } & Babi hutan/ Wild hog & Sus scrofa Linnaeus (Suidae) & Meat \\
\hline & Rusa/ Deer & Cervus timorensis (Blainville, 1822). (Cervidae) & Meat \\
\hline
\end{tabular}

The Auyu ethnic group has a traditional conservation system that has been inherited for generations from their ancestors. This is reflected in the procedures for the use of nature and forests in the local wisdom. For example, in customary rules, sago trees cannot be traded because sago is a food source. If anybody cut down sago in a village, there will be fights and even bloodshed. Until now, even ifa community's own sago land is very minimal in extent, the community highly valued customs that prohibits cutting of sago in other hamlets. In sago custom can be given to other communities if someone has contributed to the community of the owner of the sago village. For example, assisting in warfare, as compensation for community service, the owner of the village can give part of the village to the person who contributed. This can be related to the culture of sago utilization of locals in Papua (Melalatoa 1995). Furthermore, according to Kusuma et al. (2013) sago was a local food that can be used as national food support.

Second, to maintain the preservation of the community forest fauna, each community is prohibited from foraging partridge eggs (yuanggal). Likewise, hunting of Cenderawasih, birds of paradise (Ihee), is forbidden in the tradition. If it happens, there will be a war between the people because, traditionally, Cenderawasih which is very heroic but humble in its nature, is valued for its magical power and heroic courage.

Third, in the case of hunting, all animal species must be brought home and must not be buried in the hunting grounds. Fourth, in the use of customary land, community members must ask permission from the customary rights owner. Likewise, if the community hunts beyond the hamlet border, it must notify the hamlet owner and the game must be shared equally with the hamlet owner.
Fifth, the Auyu Tribe has a tradition of cultivating gardens. To start planting, a family gathering is carried out to plan the gardening activity. The procedure for family gatherings is usually to burn sago, banana, and taro. The division of labor in processing applies within the Auyu ethnicity. Activities like clearing the land, burning the weeds, sowing the seeds and harvesting are carried out jointly by both men and women. To determine the suitable time of planting, the community always depends on natural signs. Usually, clearing of land is carried out in the summer and during the rainy season, seedlings are spread. During harvest, the first plants harvested should be reserved for rituals as offerings to the ancestors and they should not be eaten.

Based on the land-use procedure, the customary community in the Kesatuan Hidrologi Gambut (KHG) or Peat Hydrology Unit has regulations that have been passed down for generations. For example, the provisions restrict cutting down trees of certain types and sizes. This is because it has been agreed that trees will be used as raw material for making boats and agarwood as building materials for social facilities. There are also rules not to steal natural resources from the village of other clans. People are also encouraged to hunt using traditional tools such as arrows. For generations, maintaining these traditional regulations are the responsibility of each clan. There are species of trees and animals that are allowed to be cut down or hunted. However, the community must pay special attention when hunting, not to catch endangered and protected animals, such as Cenderawasih birds and deer. 


\section{Biodiversity potential of the peat restoration management program}

The locals depend on forests with customary management. Many natural resources in the form of flora, fauna, including fish species and various types of mammals needed by the community for various purposes (Table 3) are provided by these forests. Some types of plants that are used from peat swamp forests include sago (Metroxylon sagu) (Mubekti 2013), agarwood (Aquilaria sp), gambier (Endriandra vulva), masohi (Cryptocarya spp.), and bus (Melaleuca leucadendron). Products such as cocoa and rubber are the result of community cultivation. Many animals, especially fishes (Ohee 2017), pigs, deer, cuscus, and large animals are obtained from peat swamp forest areas and become a source of life for local people (Beehler et al. 2001). Various important and protected bird species, such as the Cenderawasih bird which is Papua's endemic bird, are also commonly found.

Based on field data, several types of plants and plant products, such as rubber trees, gambier bark, mace oil, masohi oil, and aloes, could be developed as a source of community income. But for now, the only prima donna for the community is the exploitation of gambier barks from the forest. The selling price of gambier at the farm level ranges between Rp. 2,000-2,500 /kg, while in the subdistrict capital the price is Rp. $3,000 / \mathrm{kg}$. If it continues only by relying on the population existing in the forest without being accompanied by cultivation efforts, it will suffer the same fate as that of agarwood and masohi. Local culture which depended on the availability of natural gambier is affect their existence. This plant species can be said to be very rarely found around the village. According to the locals, gambier wood was found in the peat forest, in the deeper parts.

Rubber tapping activities, lawang oil, and masohi oil businesses did not run due to unstable market prices. The game from animals and fish so far used mainly for the daily consumption of the family. In some parts of the villages where transportation is available, some hunted products are sold in the city of Bade or Kepi.

The hunt for Cenderawasih birds is also still carried out by the locals. Exploitation of Cenderawasih birds in traditional cultural rituals encourages hunting which is still ongoing. Cenderawasih Birds are widely used by most indigenous people, and they are not exploited only by local communities. Cenderawasih birds are traded at cheap prices between Rp. 400,000-600,000-per animal in preserved condition. The demand for Cenderawasih birds is also still high and occurs in several regions in Papua. Hunting of other animals such as deer (Cervus timorense) and pigs (Sus scrofa) is carried out to fulfill protein needs. Usually, hunting is done to meet the large quantity of food needs during traditional events.

Habitat conservation must also be considered because it is one of the keys to success in protecting and preserving the bird population (Yule 2010). Cenderawasih bird is indeed unique, interesting and is a concern of the world because of its beauty. This bird has specific habitat requirements to breed, play and forage, so more research is needed. In some other places, Cenderawasih birds are traded at much higher prices, market demand is even greater, although the law has stipulated that this bird is one of the protected bird species.

Locals dependency on forests is very high (Alwi and Hairani 2007; Anonim 2010; Worbes et al. 2017). This condition shows that the importance of forests greatly determines survival for the locals (Dephut 2005; Dirjen BPK 2005; Alwi and Hairani 2007). The culture of hunting and gathering which is still the backbone of people's lives will work if there is sufficient availability in the forest (Budianta 2003; Adi et al. 2004). For this reason, demands for revegetation and revitalization of the community's economy must be carried out immediately.

\section{ACKNOWLEDGEMENTS}

The authors wish to thank the Badan Restorasi Gambut (BRG) Republik Indonesia (Peat Restoration Agency) for providing financial support into this research. The authors also thank the Cenderawasih University Institute for Research and Community Service, Lembaga Penelitian dan Pengabdian Masyarakat (LPPM) (Institute for Research and Community Service), which has fully supported the study of peats in Papua.

\section{REFERENCES}

Adi J, Setiadi B, Rieley JO. 2004. Hydrology and carbon deposit in Middle Kalimantan's peatland: The effect of PLG project and possibility of restoration. Jurnal Air, Lahan dan Mitigasi Bencana. Alami 9 (1): 27-34. [Indonesian]

Alwi M, Hairani A. 2007. Chemical characteristic of shallow peatland and its potency as chilies and tomatoes landscaping. Bul Agron 35 (1): 3643. [Indonesian]

Amias F. 2013. The Auyu were threatened of losing natural forest for palm. https://awasmifee.potager.org/?=p=338\&lang=id. [1 October 2018]. [Indonesian]

Anonim. 2010. Plan of an integrative research (RPI) in managerial of peatland in 2010-2014. 5 RPI codification. Jakarta. [Indonesian]

Barchia MF. 2017. Peat: Agroecosystem and carbon transformation. Gadjah Mada University Press. Yogyakarta. [Indonesian]

Beehler B, Pratt T, Zimmerman D. 2001. Birds in the Papua Region. Lembaga Ilmu Pengetahuan Indonesia-BirdLife International Indonesia Programme, Bogor. [Indonesian]

Budianta D. 2003. Peatland utilization strategy based on environmental concept. Proyek Climate Change, Forests and Peatlands in Indonesia. Wetland International. Jakarta. [Indonesian]

Chokkalingam U, Kurniawan I, Ruchiat Y. 2005. Fire, Livelihoods, and environmental change in the middle Mahakam peatlands, East Kalimantan. Ecol Soc 10 (1): 26-44.

Dephut (Departemen Kehutanan). 2005. The construction of plants forest at peatland area. Jakarta. [Indonesian]

Dirjen BPK (Direktorat Jenderal Bina Produksi Kehutanan). 2005. The construction of HTI at peatland area: challenge and reality. Seminar of HTI contruction at peatland. Pg. 3-4. Bogor, 14 September 2005. [Indonesian]

Driessen PM. 1978. Peat soils. In: IRRI. Soils and Rice. IRRI, Los Banos, Philippines.

Hansen MC, Stehman SV, Potapov PV, Arunarwati B, Stolle F, Pittman K. 2009. Quantifying changes in the rates of forest clearing in Indonesia from 1990 to 2005 using remotely sensed data sets. Environ Res Lett 4. DOI: 10.1088/1748-9326/4/3/034001.

Hergoualch K, Carmenta R, Atmadja S, Martius C, Murdiyarso D, Purnomo H. 2018. Managing peatlands in Indonesia, Challenges and opportunities for local and global communities. Info Brief 205: 1-8. 
Kusuma PTWW, Indrianti N, Ekafitri R. 2013. Potential of sago plant (Metroxylon sp.) to support food security in Indonesia. Pangan 22 (1) 61-76.

Lubis ZB. 2013. Social mapping of access to peat swamp forest and peatland resources. Kalimantan Forests and Climate Partnership (KFCP), Kalimantan.

Melalatoa JM. 1995. Ethnic Encyclopedia in Indonesia. Jakarta [Indonesian]

Mubekti. 2013. Spatial statistics for estimating sago stock in West Papua, Indonesia. Jurnal Teknologi Lingkungan 14 (2): 95-100.

Ohee HL. 2017. Fish diversity in Southern Papua. Jurnal Biologi Papua 9 (2): 74-82. [Indonesian]

Page SE, Rieley JO, Shotyk OW, Weiss D. 1999. Interdependence of peat and vegetation in a tropical peat swamp forest. Phil Trans R Soc Lond B Biol Sci. 354 (1391): 1885-1897.

Posa MRC, Wijedasa LS, Corlett RT. 2011. Biodiversity and conservation of tropical peat swamp forests. BioSci 61 (1): 49-57.

Ratmini NPS. 2012. Characteristic and peatland managerial for agricultural development. J Lahan Suboptimal 1 (2): 197-206. [Indonesian]

Rudiyanto BI, Setiawan, Arief C, Saptomo SK, Gunawan A, Kuswarman, Sungkono, Indriyanto H. 2015. Estimating distribution of carbon stock in tropical peatland using a combination of an empirical peat depth model and GIS. Procedia Environ Sci 24: 152-157.

Silvius, M. J., Suryadiputra, N. 2005. Review of policies and practices in tropical peat swamp forest management in Indonesia. Wetlands Indonesia. Jakarta
Sorensen KW. 1993. Indonesian peat swamp forests and their role as a carbon sink. Chemosphere 27 (6): 1065-1082

Wahyunto, Suparto, Bambang H, Bhekti H. 2006. Scattered peatland, size, and carbon stocks under the land of Papua. Proyek Climate Change, Forests and Peatlands in Indonesia. Proyek Climate Change, Forests and Peatlands in Indonesia. Wetland Internasional-Indonesia Programme dan Wildlife Habitat Canada, Bogor. [Indonesian]

Warren M, Hergoualch K, Kaufman JB, Murdiyarso D, Kolka R. 2017. An appraisal of Indonesia's immense peat carbon stock using national peatland maps: uncertainties and potential losses from conversion. Carbon Balance Manag 12: 12. DOI 10.1186/s13021-017-0080-2.

Wetlands International Indonesia Programme. 2006. Distribution of peatlands, area and subsurface carbon stock in Papua. Wetlands International, Indonesia Programme, Bogor. [Indonesian]

Wibowo P, Suyatno N. 1998. An overview of Indonesian wetlands sitesII. Wetlands International-Indonesia Programme (WI-IP). Jakarta.

Winarso S. 2005. Soil fertility: Basic health and soil quality. Gava Media, Yogyakarta. [Indonesian]

Womersley JS. 1995. Handbooks of the flora of Papua New Guinea. Vol 1-3. Melbourne University Press. Australia.

Worbes M, Herawati H, Martius C.2017. Tree growth rings in tropical peat swamp forests of Kalimantan, Indonesia. Forests 8: 336. DOI: $10.3390 / \mathrm{f} 8090336$

Yule CM. 2010. Loss of biodiversity and ecosystem functioning in IndoMalayan peat swamp forests. Biodiv Conserv 19: 393-409. 